\title{
HYDROTHERMAL ALTERATION IN THE LOWER PART OF AN EARLY PROTEROZOIC GREENSTONE COMPLEX AT PALOVAARA, ENONTEKIÖ, NORTHWESTERN FINLAND
}

\author{
PASI EILU and HANNU IDMAN
}

\begin{abstract}
EILU, PASI and IDMAN, HANNU, 1988: Hydrothermal alteration in the lower part of an early Proterozoic greenstone complex at Palovaara, Enontekiö, northwestern Finland. Bull. Geol. Soc. Finland 60, Part 2, 115-127.
\end{abstract}

The lower part of the early Proterozoic greenstone complex at Palovaara, northwestern Finnish Lapland, comprises a quartzite formation overlain by intermediate and felsic tuffs and tuffites with some lava flows, mostly intermediate in chemical composition. They are intruded by numerous sills of albite diabase and also by some minor keratophyric dykes.

The lithology and geochemistry of the rocks are similar to those of the spilitekeratophyre association and provide evidence that the rocks were thoroughly altered by postcrystallization processes.

Geochemically, all the rock types, including the extrusive and subvolcanic varieties, are greatly enriched in $\mathrm{Na}$ and depleted in $\mathrm{K}$ and $\mathrm{Mn}$. The alteration resembles that observed in recent submarine volcanics, whose mineralogy is largely governed by the water/rock ratio during alteration. Subsequent regional metamorphism had only a minor, if any, effect on the geochemistry of the rocks but adjusted the mineralogy to the conditions of epidote-amphibolite facies.

The analytical data on lavas and albite diabases suggest an increase in $\mathrm{Na}, \mathrm{Si}$, $\mathrm{Al}$ and $\mathrm{Ti}$ and a decrease in total $\mathrm{Fe}, \mathrm{Mn}, \mathrm{Mg}$ and $\mathrm{Ca}$, with an increase in $\mathrm{w} / \mathrm{r}$ ratios from low to moderate values, thus reflecting intensifying albitization of the host rock. Further intensification of the water-rock interaction resulted in a dramatic change in alteration. The most permeable parts of the rocks, such as the interpillow matrices, pillow selvages and some of the fractures plus their wall rocks, acquired an ultramafic mineral composition with a marked increase in $\mathrm{Fe}$ and $\mathrm{Ca}$ and a decrease in $\mathrm{Si}$ and $\mathrm{Na}$. A K-metasomatic event that postdated the general hydrothermal alteration locally raised the $\mathrm{K}$-content of the rocks.

Key words: metavolcanic rocks, diabase, chemical composition, metasomatism, hydrothermal alteration, albitization, Proterozoic, Palovaara, Enontekiö, Finland.

Pasi Eilu: Roos Oy, SF-21360 Lieto, Finland.

Hannu Idman: Geological Survey of Finland, SF-02150 Espoo, Finland.

\section{Introduction}

The main emphasis of this paper is on the metasomatic alteration of volcanic rocks resembling the spilitekeratophyre association. The material for the study was collected during regional mapping of the Palovaara area carried out by the Geological Survey of Finland in 1982 - 83. The study was based on the description of the rock types and on 46 chemical silicate analyses. We used the results from experimental studies and from recent sea floor 


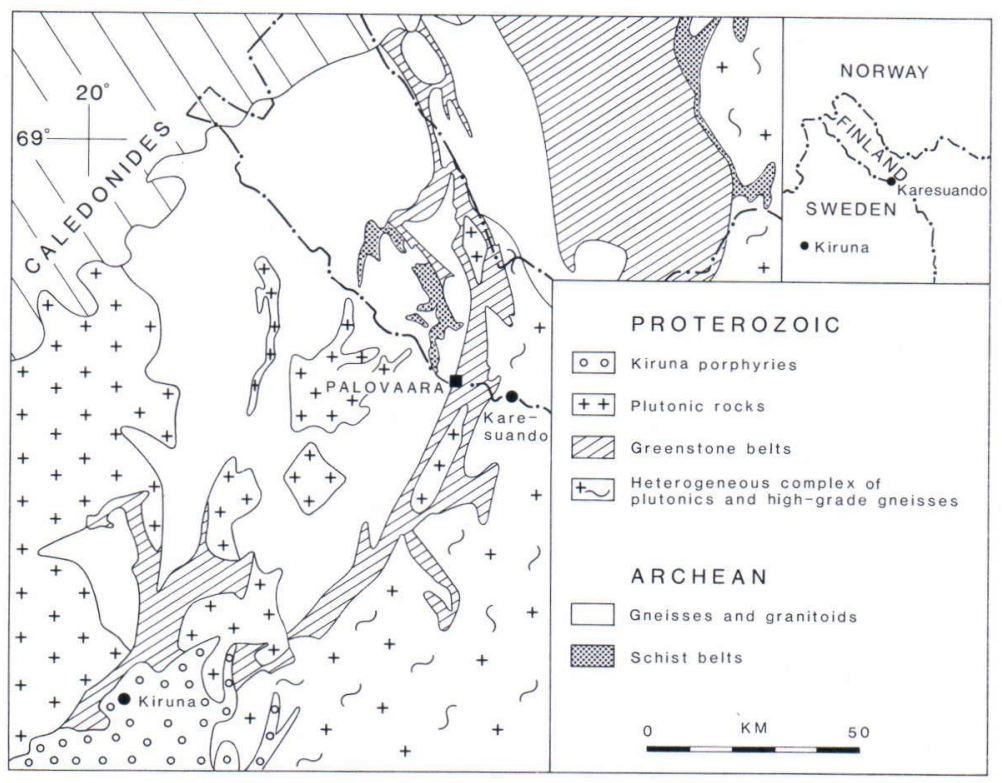

Fig. 1. Generalized geological map of northern Lapland with the location of the Palovaara area (Geological Map of Northern Fennoscandia). studies to interpret the chemical trends of the alteration and the conditions under which the rocks were altered. All the samples were analysed for main components and $\mathrm{Zr}$ using the XRF technique.

\section{Geological setting}

The greenstone complex extends northwards from the Kiruna area in Sweden across the extreme northwest, the "Arm», of Finland up to Norway, where it is buried below younger Caledonian schists. It is bounded by Archaean rocks to the west and by a Proterozoic, heterogeneous complex of plutonic rocks and highgrade gneisses to the east (Fig.1).

Witschard (1984) suggests that the greenstone complex was deposited along a graben-type depression in the Archaean craton during a tensional rifting episode. This view is consistent with geochronological studies conducted in northern Sweden. According to Skiöld (1986), initiative magmatism in the opening depression began about $2.2 \mathrm{Ga}$ ago, whereas metamorphism of the greenstones took place much later, about $1.9 \mathrm{Ga}$ ago.

\section{Geology of the Palovaara area}

\section{Lithology}

In the study area at Palovaara (Fig.2) a sequence of predominantly extrusive and subvolcanic rocks about one kilometre thick is exposed on the western flank of a synclinorial structure some $7 \mathrm{~km}$ wide. The western part of the study area (Fig. 2) comprises a massive granitoid overlain by a $200-300 \mathrm{~m}$ thick quartzite formation, that is the lowermost lithostratigraphic unit of the greenstone complex. The quartzite is a physical continuation of the well-known Tjärro-quartzite in northern Sweden (e.g. Ambros 1980). The contact of the granitoid below the quartzite is altered (seritized) to a depth of $2-8 \mathrm{~m}$, presumably indicating an ancient paleosol. This supposition is supported by radiometric U-Pb zircon dating, which suggests an Archaean age (about 2.7 $\mathrm{Ga}$ ) for the granitoid at Palovaara (Idman and Eilu 1988). 


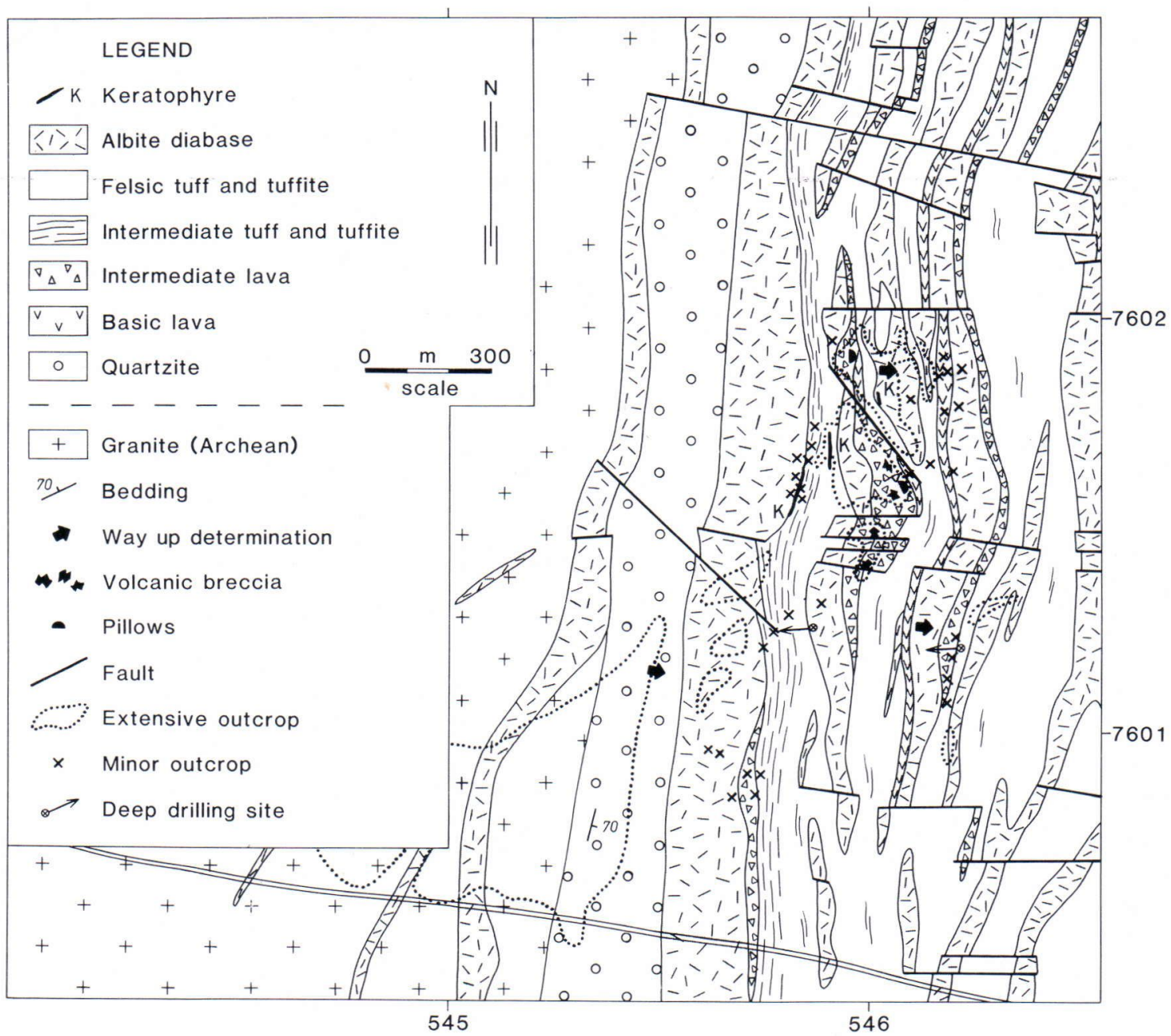

Fig. 2. Geological map of the Palovaara area.

The most striking feature on the geological map of the area is the presence of numerous subparallel albite diabase intrusions varying in thickness from 10 to $200 \mathrm{~m}$. They are roughly conformable with the layered structure of the greenstone complex, whereas the dykes outside the complex clearly cut the Archaean wall rock. The rocks between the albite diabase sills are finegrained felsic and intermediate micaceous tuffs and tuffites, and intermediate lava flows; mafic lavas are scarse. A few thin horizons of scapolite tuff and magnetite tuff occur in the more fel- sic tuffs. The intermediate lavas are locally pillowed, indicating deposition in a subaqueous environment. The keratophyres, which occur as minor dykes no more than $4 \mathrm{~m}$ thick, are the youngest rock type, as they intrude the albite diabase sills, too.

\section{Petrography}

Lavas

The lavas at Palovaara are usually subophitic or trachytoid and sometimes microporphyritic in 
texture (terminology after Mackenzie et al. 1982). Albite and amphibole are the main minerals in both the mafic and the intermediate lavas. Epidote, biotite, sphene or rutile and magnetite are common minor constituents except in one mafic flow, which is devoid of epidote.

The intermediate lavas are more heterogeneous in appearance than the mafic lavas, and owing to the patches and schlieren of epidote and epidote-amphibole, which vary in size from a few centimetres to several metres, are sometimes very prominent (Fig. 3a). Around the patches the wall rock is frequently bleached to a depth of several centimetres as a result of albitization. Fractures and veins, $1 \mathrm{~mm}$ to some centimetres wide and filled with light-coloured albite or darker epidoteamphibole, intersect the lavas and are often surrounded by a much thicker, bleached (albitized) halo.

The pillows, varying in size from 15 to $200 \mathrm{~cm}$, exhibit a zoned structure (Fig. 3b). The inner part of the pillows is greenish-grey, becoming gradually lighter towards the margins owing to an increase in albitization. The pillow selvages are commonly double-zoned, with an inner rim of epidote and an outer rim rich in amphibole. The interpillow matrix is dark and invariably rich in amphibole or amphibole + epidote with relics of chlorite.

Felsic and intermediate tuffs and tuffites

The tuffs and tuffites are fine-grained rocks that, on the basis of their mineralogy, can be divided into two types: a grey or greenish one rich in mica and a felsic type. The former is made up of albite, biotite, paragonite, chlorite and pyrophyllite in widely varying proportions, while the latter consists mainly of albite, quartz and paragonite. Transitional types are also encountered. Epidote, zircon, rutile and tourmaline occur as accessory minerals, and in places the tuffs are rich in carbonate. Porphyroblastic needles of amphibole are common in both tuff types.

Fractures $0.1-10 \mathrm{~mm}$ thick and filled with al- bite, quartz and biotite frequently intersect the more mafic tuffs. The host rock is bleached around the fractures to a width of $10 \mathrm{~cm}$ (Fig. 3c). Mineralogically, the bleaching implies a loss of biotite, amphibole, magnetite and chlorite and an increase in albite, paragonite and rutile.

The felsic tuffs do not show any bleached fractures on outcrop scale. However, microscopically, the fine-grained matrixis intersected by coarser-grained veinlets with abundant albite plus varying amounts of carbonate and paragonite. These veinlets are obviously of secondary origin and comparable to the visible veining of the more mafic tuffs.

\section{The albite diabases}

The intrusions show both mineralogical and chemical differentiation, with the bottom section enriched in mafic minerals (Fig. 4), probably as a result of gravitational crystal settling. The albite diabases are medium to coarse-grained rocks with intergranular or, sometimes, trachytoid textures (MacKenzie et al. 1982). Ophitic texture is seen only in the most coarse-grained varieties. The original cumulate texture is often preserved.

The dominant rock type has virtually the same mineral assemblage as the lavas, i.e. albite + amphibole + epidote, with the ultramafic part composed of amphibole + biotite. Albite is clearly a decomposition product of more calcic plagioclase, as the plagioclase is clouded by abundant epidote. Amphibole seems to be mostly pseudomorphous after primary clinopyroxene. The abundance of sphene and, particularly, that of magnetite amounts to a few per cent, while rutile, apatite, iron sulphide and zircon are minor accessory minerals. The biotite in the ultramafic types is mainly an alteration product of amphibole.

Varying in size between 1 and $100 \mathrm{~cm}$, lightgreen patches rich in epidote and darker patches and veinlets rich in amphibole with occasional relics of chlorite have developed in the albite diabases in places. Slightly brecciated and bleached 

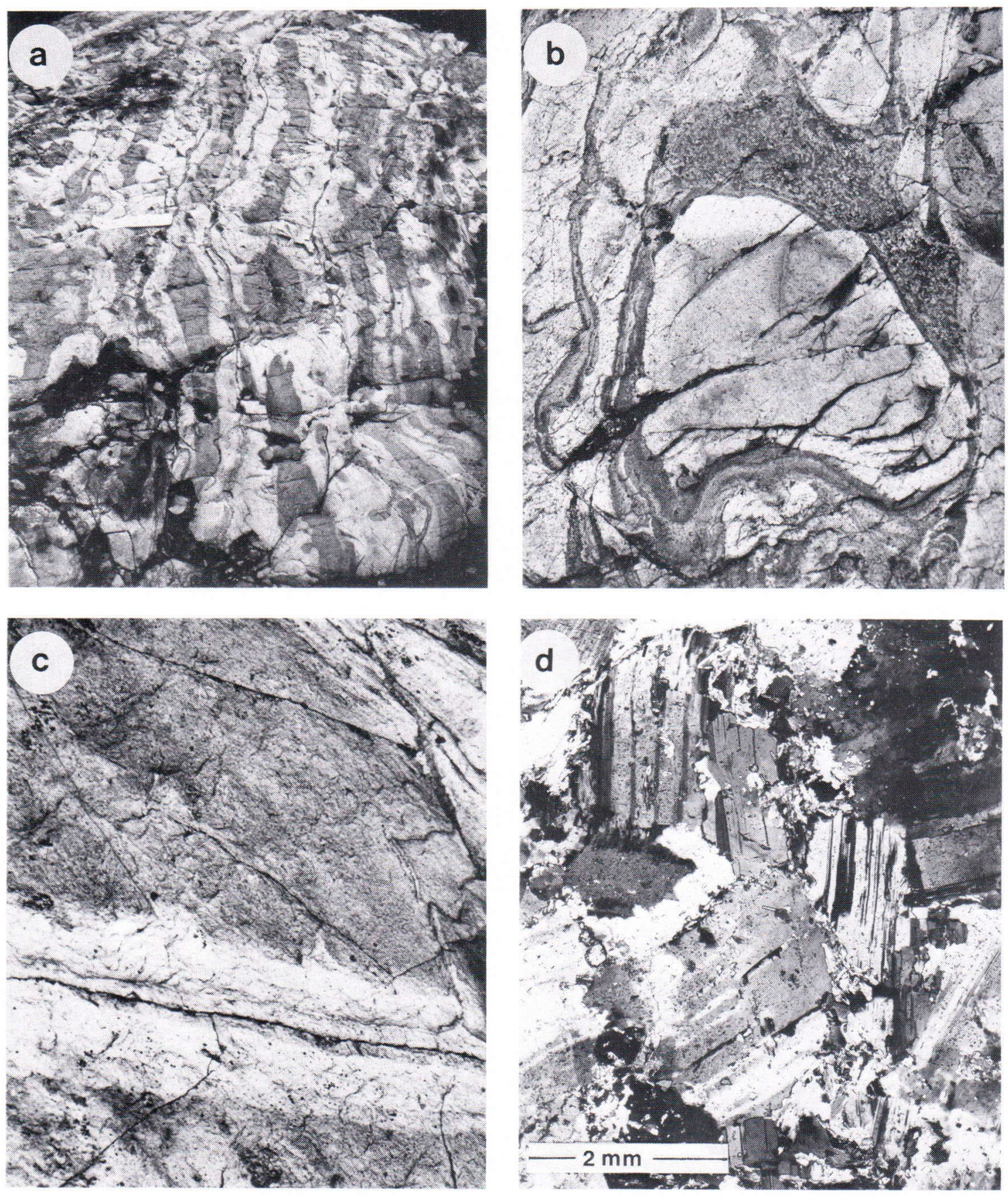

Fig. 3. Macroscopic and microscopic features of volcanic rocks at Palovaara. a) Intermediate lava showing darker bandlike bodies rich in amphibole + epidote, with light-coloured (bleached) interband areas. Width of outcrop $2 \times 4 \mathrm{~m}$. b) Pillow lava showing dark interpillow matrix and pillow selvages (rich in amphibole + epidote), a homogeneous core and visibly bleached (albitized) outer part of a pillow. Diameter of pillow $25 \mathrm{~cm}$. c) A fracture in a paragonite-pyrophyllite tuff showing a bleached halo c. $4 \mathrm{~cm}$ in width. d) Microphoto of a strongly albitized albite diabase sill (zone $43-59 \mathrm{~m}$ in Fig. 4). 
zones are also found. Some of the zones are rather thick, as for instance the $43-59 \mathrm{~m}$ zone in the drilling profile in Fig. 4. These bleached zones are rich in clear granular albite displaying a mosaic of composite twinning (Fig. 3d). Carbonate and, especially, biotite fill the fractures and intergranular spaces.

\section{Keratophyres}

Both keratophyres and quartz-keratophyres (terminology after Schermerhorn 1973) occur as narrow dykes at Palovaara, but unlike in other rock types, no filled fractures are seen. Further, compared with other rock types they look very »fresh» under the microscope, showing a glomeroporphyric texture.

The anortite content of the zoned phenocrysts of plagioclase varies between 0 and 20 per cent. The plagioclase in the matrix is always albitic. Idiomorphic zircon and apatite are common accessory minerals in both keratophyric types.

\section{Geochemistry}

The petrography of the rock types indicates strong alteration. Further evidence is given by the geochemistry of the magmatic rock types, which, as a group, plot far outside the igneous spectrum in Figs. 5a and b. Less mobile elements, such as $\mathrm{Ti}$ and $\mathrm{Zr}$ in the silica vs. Ti/Zr diagram (Fig. 6), indicate that the rocks do not fit into an alkalic rock series, which would explain their high concentrations of $\mathrm{Na}$, as shown in Fig. 5. The plots indicating low contents of $\mathrm{Na} 2 \mathrm{O}$ and high $\mathrm{K} 2 \mathrm{O}$ / $(\mathrm{K} 2 \mathrm{O}+\mathrm{Na} 2 \mathrm{O})$ ratios are due to ultramafic cumulates of the albite diabases.

Figures 5 and 6 also include the visibly unaltered rock types, suggesting, that alteration was a pervasive process. Tuffs and tuffites, most of which are not plotted in the diagrams, and even those rich in biotite, also have exceptionally high $\mathrm{Na} / \mathrm{K}$ ratios, indicating that all the rock types at Palovaara were subjected to similar metasomatic processes.

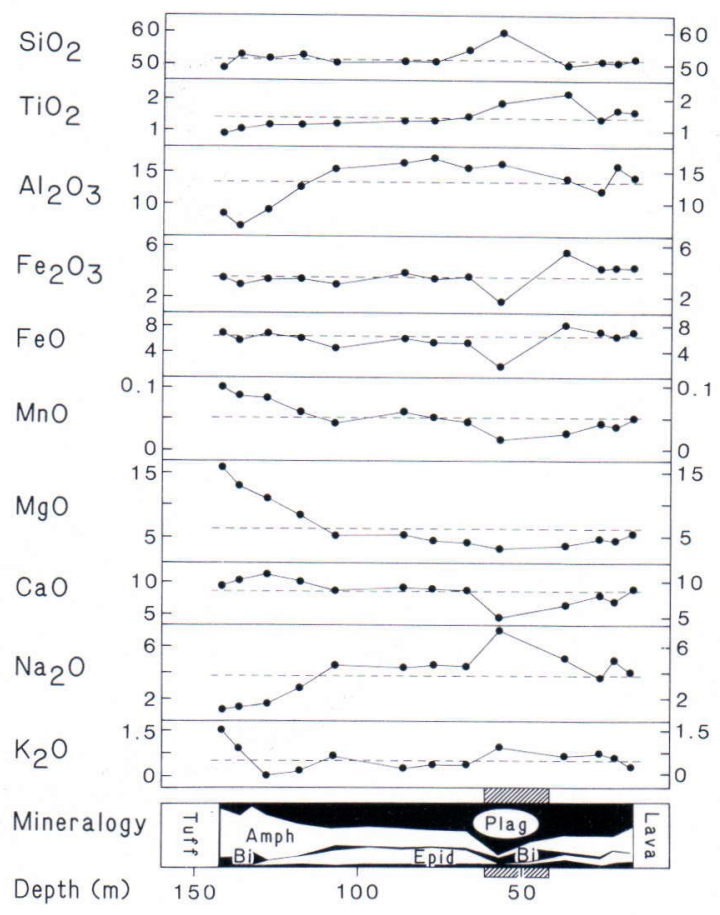

Fig. 4. Chemical and mineralogical profile of drill core covering an albite diabase sill. The brecciated and bleached (albitized) zone at $43-59 \mathrm{~m}$ is hatched on both sides of the mineralogy box. Dashed lines indicate weighted means of the sill excluding the strongly albitized zone.

The albite diabases deserve some comment. Being widely distributed in northern and eastern Finland, they have been described by many geologists. Their unusual mineralogy and geochemistry have been attributed to metasomatism (e.g. Eskola 1925, Meriläinen 1961) or interpreted as a primary feature (Paakkola 1971, Piispanen 1972, Piirainen and Rouhunkoski 1974). More recently, Hanski $(1984,1986,1987)$ has produced petrogenetic evidence that these rocks, or at least some of them, are members of the gabbro-wehrlite association. However, he favours a secondary origin for the albite. As stated above, the geochemical composition of all the rock types at Palovaara as a group suggests that metasomatism played an important role in the albite diabases, too. 
(a)

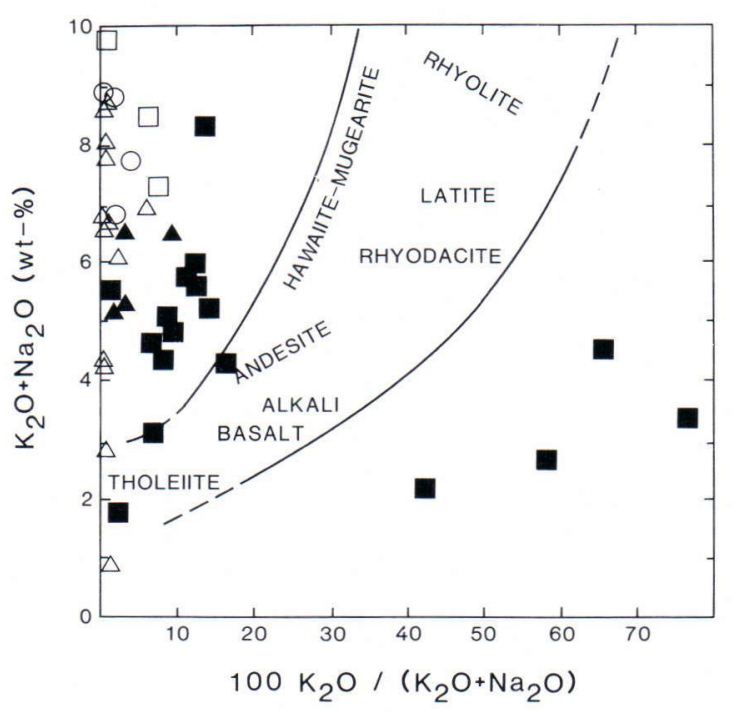

albite diabase

- mafic lava

$\triangle$ intermediate lava (b)

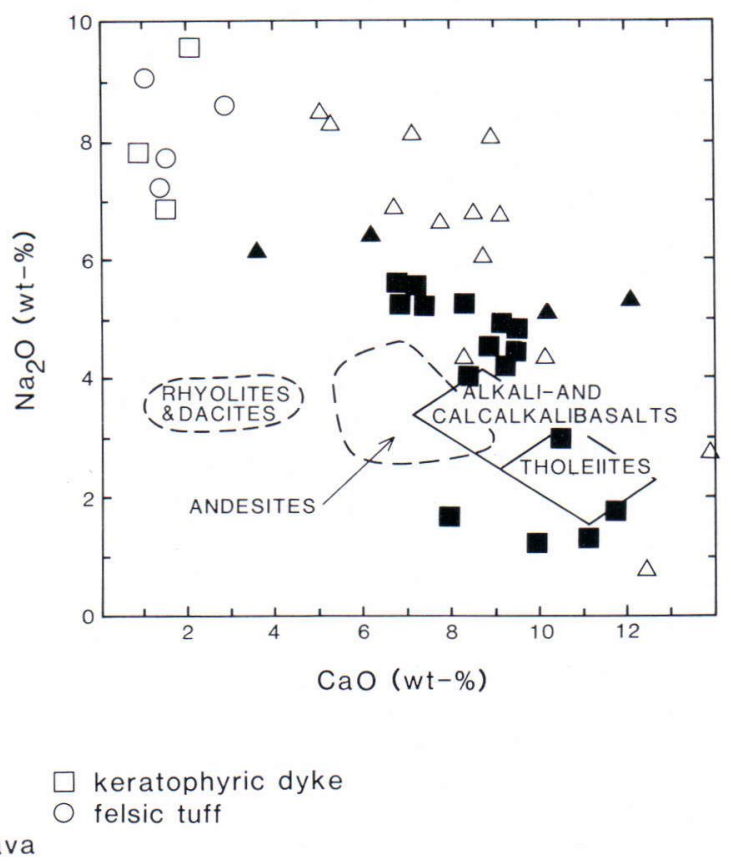

Fig. 5. $\mathrm{Na}_{2} \mathrm{O}+\mathrm{K}_{2} \mathrm{O}$ vs. $\mathrm{K}_{2} \mathrm{O} /\left(\mathrm{K}_{2} \mathrm{O}+\mathrm{Na}_{2} \mathrm{O}\right)$ plot (a) and $\mathrm{Na}_{2} \mathrm{O}$ vs. $\mathrm{CaO}$ plot (b) of igneous rocks and homogeneous felsic tuffs from Palovaara. The igneous spectrum in a) is that of Hughes (1973) and the primary fields of basalts and rhyolites + dacites in b) are from Stephens (1980). The andesite field was constructed by the authors from data collected by Kähkönen (1981).

\section{Metasomatic alteration}

It is not possible to trace exactly the chemical changes that took place in the volcanic rocks at Palovaara, since rocks with primary compositions are not to be found there. However, the overall trends of the alteration can be characterized by comparing the compositions of the volcanic rocks with those of recent volcanics and also by comparing the less altered types with the more altered ones. With regard to the albite diabases, some deductions can be made by drawing analogies with the volcanics at Palovaara, and by comparing present data with those on »normal» diabases.

Representative chemical analyses of rocks from Palovaara and of relevant comparative rocks are

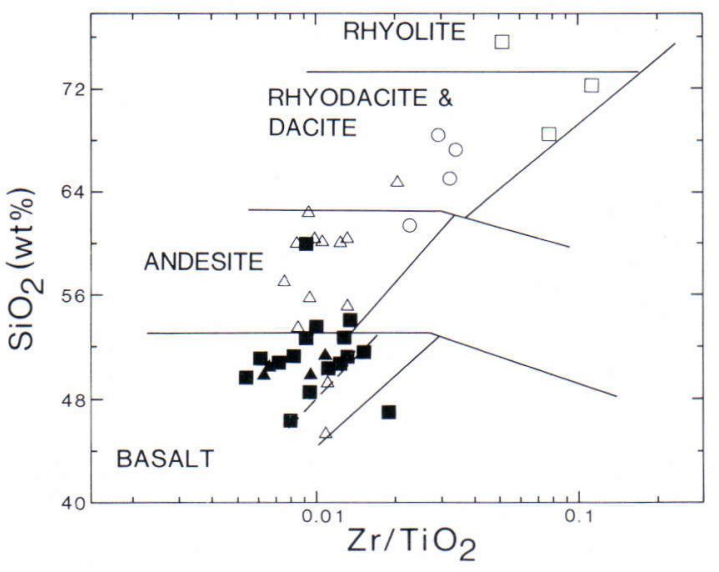

Fig. 6. $\mathrm{SiO}_{2}$ vs. $\mathrm{Zr} / \mathrm{TiO}_{2}$ plot (Floyd and Winchester 1978) from Palovaara. The homogeneous felsic tuffs included for comparison. Subalkalic basalts to the right of the dashed line in the basalt field. For legend, see Fig. 5. 
Table 1. Representative chemical compositions from Palovaara. For comparison, analyses of unaltered volcanics and diabases from the literature (Le Maitre 1976) are also given.

\begin{tabular}{|c|c|c|c|c|c|c|c|c|c|c|c|c|}
\hline & 1 & 2 & $3^{*}$ & 4 & $5^{*}$ & $6^{*}$ & 7 & 8 & 9 & 10 & 11 & 12 \\
\hline $\mathrm{SiO}_{2}$ & 50.93 & 60.00 & 50.14 & 50.49 & 49.20 & 49.58 & 58.22 & 45.28 & 59.91 & 53.50 & 59.98 & 49.23 \\
\hline $\mathrm{TiO}_{2}$ & 1.33 & 1.85 & 1.49 & 1.72 & 1.84 & 1.98 & 1.44 & 2.36 & 2.28 & 1.89 & 2.10 & 2.36 \\
\hline $\mathrm{Al}_{2} \mathrm{O}_{3}$ & 12.83 & 16.29 & 15.02 & 14.72 & 15.74 & 14.79 & 14.08 & 15.14 & 13.61 & 16.38 & 17.21 & 17.75 \\
\hline $\mathrm{Fe}_{2} \mathrm{O}_{3}$ & 10.99 & 3.32 & 3.45 & 11.56 & 3.79 & 3.38 & 5.88 & 11.03 & 5.11 & 6.78 & 3.11 & 9.36 \\
\hline $\mathrm{FeO}$ & - & - & 8.16 & - & 7.13 & 8.03 & - & - & - & - & - & - \\
\hline $\mathrm{MnO}$ & .06 & .02 & .16 & .04 & .20 & .18 & .04 & .10 & .05 & .02 & .02 & .04 \\
\hline $\mathrm{MgO}$ & 7.62 & 3.03 & 6.40 & 8.01 & 6.73 & 7.30 & 5.98 & 4.64 & 5.66 & 2.88 & 2.61 & 4.48 \\
\hline $\mathrm{CaO}$ & 8.65 & 4.17 & 8.90 & 7.93 & 9.47 & 10.36 & 8.81 & 17.35 & 6.52 & 8.58 & 7.05 & 14.07 \\
\hline $\mathrm{Na}_{2} \mathrm{O}$ & 3.44 & 7.37 & 2.91 & 5.61 & 2.91 & 2.37 & 5.31 & .86 & 6.72 & 7.77 & 8.04 & 2.77 \\
\hline $\mathrm{K}_{2} \mathrm{O}$ & .73 & .96 & .99 & .24 & 1.10 & .43 & .04 & .01 & .02 & .03 & .02 & .02 \\
\hline \multirow[t]{2}{*}{$\mathrm{n}$} & 14 & 1 & 405 & 4 & 3594 & 202 & 4 & 1 & 1 & 1 & 1 & 1 \\
\hline & 13 & $14^{*}$ & 15 & 16 & $17 *$ & $18^{*}$ & 19 & 20 & 21 & 22 & 23 & 24 \\
\hline $\mathrm{SiO}_{2}$ & 63.55 & 57.94 & 73.70 & 68.20 & 72.82 & 65.55 & 66.57 & 62.41 & 62.60 & 62.90 & 60.80 & 63.90 \\
\hline $\mathrm{TiO}_{2}$ & 1.99 & .87 & .21 & .91 & .28 & .60 & .58 & .70 & .72 & .70 & .74 & .69 \\
\hline $\mathrm{Al}_{2} \mathrm{O}_{3}$ & 16.99 & 17.02 & 17.09 & 18.90 & 13.27 & 15.04 & 15.04 & 16.10 & 18.04 & 14.93 & 15.79 & 13.73 \\
\hline $\mathrm{Fe}_{2} \mathrm{O}_{3}$ & 4.05 & 3.12 & 1.61 & 1.34 & 1.48 & 2.13 & 1.37 & 4.58 & 3.82 & 1.71 & 3.90 & 1.19 \\
\hline $\mathrm{FeO}$ & - & 4.04 & - & - & 1.11 & 2.03 & - & - & - & - & - & - \\
\hline $\mathrm{MnO}$ & .00 & .14 & .01 & .01 & .06 & .09 & .00 & .00 & .00 & .00 & .00 & .00 \\
\hline $\mathrm{MgO}$ & 2.61 & 3.33 & .63 & 1.35 & .39 & 2.09 & 3.69 & 4.41 & 3.41 & 4.92 & 8.42 & 8.24 \\
\hline $\mathrm{CaO}$ & 5.24 & 6.79 & 1.22 & 2.12 & 1.14 & 3.62 & 1.64 & 1.47 & .22 & .20 & .87 & .84 \\
\hline $\mathrm{Na}_{2} \mathrm{O}$ & 8.53 & 3.48 & 7.42 & 9.71 & 3.55 & 3.67 & 7.82 & 5.00 & 7.73 & 7.50 & 6.34 & 5.66 \\
\hline $\mathrm{K}_{2} \mathrm{O}$ & .01 & 1.62 & .46 & .02 & 4.30 & 3.00 & .08 & 1.45 & .01 & .02 & 1.64 & .61 \\
\hline $\mathrm{n}$ & 2 & 2600 & 2 & 1 & 670 & 100 & 4 & 4 & 1 & 1 & 1 & 1 \\
\hline
\end{tabular}

$-=$ not determined

$\mathrm{Fe}_{2} \mathrm{O}_{3}=$ calculated total iron if $\mathrm{FeO}$ not given

* = comparative analyses from the literature (Le Maitre 1976)

$\mathrm{n}=$ number of analyses

1 = weighted mean of the drilled albite diabase sill; 2 = bleached (strongly albitized) and brecciated albite diabase from the drilled sill; $3^{*}=$ average of diabases (Le Maitre 1976) $4=$ average of homogeneous mafic lavas; $5^{*}=$ average of basalts (Le Maitre 1976); 6* = average of tholeiites (Le Maitre 1976); 7 = average of visibly unaltered samples from an intermediate flow; $8=$ a fracture rich in epidote and amphibole, same flow as in 7; 9 = visibly bleached (strongly albitized) country rock of epidote-amphibole fracture, same flow as in 7; $10=$ core of a pillow with some epidote fractures; $11=$ visibly bleached (strongly albitized) outer part of a pillow, same flow as in 10; 12 = pillow selvage rich in epidote and amphibole, same flow as in 10-11; 13 = massive intermediate lavas with albite-rich veins; $14^{*}=$ average of andesites (Le Maitre 1976); $15=$ average of quartz-keratophyres; $16=$ keratophyre; $17^{*}=$ average of rhyolites $($ Le Maitre 1976$) ; 18^{*}=$ average of rhyodacites (Le Maitre 1976); 19 = average of homogeneous felsic tuffs; 20 = average of intermediate biotiterich tuffs; $21=$ pyrophyllite-rich tuff or tuffite; $22=$ bleached fracture in $21 ; 23=$ biotite-rich tuff or tuffite; $24=$ bleached fracture in 23 .

compiled in Table 1. The chemical trends of alteration are shown in Table 2 .

In brief, all the volcanic rock types of the greenstone complex at Palovaara are characterized by high concentrations of $\mathrm{Na}$ and low concentrations of $\mathrm{K}$ and $\mathrm{Mn}$. This feature, which is atypical of primary igneous rocks, is due to secondary alterations reflecting albitization of the primary more calcic plagioclase and replacement of the primary mafic minerals by secondary minerals.

The lavas and the albite diabases were further enriched in $\mathrm{Si}, \mathrm{Ti}, \mathrm{Al}$ and $\mathrm{Na}$ and depleted in $\mathrm{Fe}$ (tot.), $\mathrm{Mg}, \mathrm{Mn}, \mathrm{Ca}$ and $\mathrm{K}$ at the same time as 
Table 2. Qualitative changes in the chemical compositions of different rock types at Palovaara, as deduced from the chemical analyses.

\begin{tabular}{|c|c|c|c|c|c|c|c|c|c|}
\hline & \multicolumn{4}{|c|}{ Lavas } & \multirow{2}{*}{\multicolumn{2}{|c|}{$\begin{array}{c}\text { Albite } \\
\text { diabases }\end{array}$}} & \multirow{3}{*}{$\begin{array}{c}\text { Kerat- } \\
\text { ophyres } \\
1\end{array}$} & \multirow{2}{*}{\multicolumn{2}{|c|}{$\begin{array}{l}\text { Tuffs/ } \\
\text { tuffites }\end{array}$}} \\
\hline & \multirow{2}{*}{$\begin{array}{c}\text { mafic } \\
1\end{array}$} & \multicolumn{3}{|c|}{ intermediate } & & & & & \\
\hline & & 1 & 2 & 3 & 1 & 2 & & 1 & 2 \\
\hline $\mathrm{SiO}_{2}$ & + & + & + & -- & + & + & 0 & 0 & + \\
\hline $\mathrm{TiO}_{2}$ & 0 & + & + & + & 0 & + & 0 & 0 & 0 \\
\hline $\mathrm{Al}_{2} \mathrm{O}_{3}$ & - & 0 & + & + & 0 & + & + & 0 & - \\
\hline $\mathrm{Fe}_{2} \mathrm{O}_{3} *$ & 0 & - & - & ++ & 0 & -- & - & 0 & - \\
\hline $\mathrm{MgO}$ & 0 & 0 & - & + & 0 & - & 0 & 0 & 0 \\
\hline $\mathrm{MnO}$ & -- & - - & - & + & -- & - & - - & - & + \\
\hline $\mathrm{CaO}$ & 0 & 0 & - & ++ & 0 & - & 0 & 0 & 0 \\
\hline $\mathrm{Na}_{2} \mathrm{O}$ & ++ & ++ & + & -- & ++ & ++ & ++ & + & + \\
\hline $\mathrm{K}_{2} \mathrm{O}$ & - & -- & - & 0 & - - & 0 & - - & -- & - \\
\hline
\end{tabular}

$1=$ least altered; 2 = strongly albitized (visibly bleached); 3 = patches or fractures and interpillow matrix rich in epid + amph $0=$ no essential or systematic change, or change not known; $+=$ increases or tends to increase; $++=$ clearly increases; $-=$ decreases or tends to decrease; $--=$ clearly decreases

albitization (bleaching) was intensified. As a result, not only was the more calcic plagioclase converted into albite but also new albite was introduced into the rocks or, alternatively, most of the constituents other than albite were removed. The bleached fractures in the tuffs and tuffites show other types of alteration. They are strongly depleted in $\mathrm{Fe}$ (tot.), $\mathrm{K}$ and $\mathrm{Al}$ relative to the homogeneous wall rock, mainly owing to losses in mafic minerals.

Relative to the host rock, the dark-coloured ultramafic parts of the intermediate lavas are enriched in $\mathrm{Ti}$ and $\mathrm{Al}$ and particularly in $\mathrm{Fe}$ (tot.) and $\mathrm{Ca}$, and depleted in $\mathrm{Si}$ and $\mathrm{Na}$. Though not proved by chemical assays, similar chemical trends are to be expected from the epidote-amphibole dominant fractures and bodies in albite diabases, too.

The exceptional K-enrichment in the ultramafic cumulate of the albite diabases is obviously due to a K-metasomatic event that was responsible for biotitization of amphiboles. A similar, though less distinct, $\mathrm{K}$-enrichment is also evident in the albitized zone at $43-59 \mathrm{~m}$ in the drilled sill (see Fig. 4), where biotite, predominantly confined to fractures, is younger than albite. This suggests that the K-metasomatic event postdat- ed the pervasive Na-metasomatism (albitization) of the rocks.

\section{Conditions of alteration}

The chemical composition of the rocks of the study area, high $\mathrm{Na}$ and low $\mathrm{K}$, together with characteristic rock types and low-grade mineral assemblages, are all features diagnostic to spilites and the spilite-keratophyre association (de la Roche et al. 1974, Fiala 1974). According to the present view (e.g. Large 1977, Spooner et al. 1977, Munha and Kerrich 1980, Staudigel at al. 1981, Sivell and Waterhouse 1984, Alt and Honnorez 1984, Alt et al. 1986) a spilite-keratophyre association is produced by a reaction between seawater and rocks under hydrothermal conditions. Geologically speaking, these reactions take place in a short time interval after the deposition of the rocks (probably less than $10 \mathrm{Ma}$, e.g. Staudigel et al. 1981, Ito and Andersson 1983). The depletion in Mn has also often been attributed to alteration caused by seawater-derived hydrothermal fluids (e.g. Hajash and Chandler 1981, Lagerblad and Gorbatschev 1985).

Application of the principle of seafloor 
metasomatism to Palovaara implies that regional metamorphism had but a minor, if any, effect on the rock geochemistry and only adjusted the mineralogy to the metamorphic conditions of epidote-amphibolite facies. It also implies that the interval between the intrusion of albite diabases and the effusive phase of the greenstone complex cannot have been very long. This concept is supported by the setup in the Kiruna area, where an albite diabase sill of the lower part of the Kiruna greenstone group (stratigraphically correlated to the Palovaara greenstones) shows a crystallization age of $2.2 \mathrm{Ga}$, which is close to the depositional age of the volcanics (Skiöld 1986).

Several variables, partly still unspecified, control hydrothermal reactions in seafloor conditions. However, recent experimental studies indicate that the water/rock ratio $(w / r)$ is one of the basic factors in the system (e.g. Seyfried and Bischoff 1977, Mottl and Holland 1978, Edmond et al. 1979, Hajash and Chandler 1981, Janecky and Seyfried 1983, Reed 1983). The variation in $\mathrm{w} / \mathrm{r}$ ratios results in different mineral assemblages. Most sensitive to high $\mathrm{w} / \mathrm{r}$ ratios are the porous and permeable portions of a volcanic pile, such as a matrix of pillows, breccias, fractures and so on. Massive lavas and subvolcanic intrusions are characterized by much lower $\mathrm{w} / \mathrm{r}$ ratios and, hence, by different mineral assemblages. Figure 7 illustrates the secondary assemblages in mafic rocks demonstrated by experimental studies. The dominant metamorphic assemblages of the lavas and albite diabases at Palovaara are marked in the same figure.

At Palovaara, the clearest manifestations of seawater-rock interactions are the inter-pillow matrices in andesitic lavas. Experimental studies and observations on natural samples from the sea floor show that basaltic rocks alter to ultramafic rocks under high $\mathrm{w} / \mathrm{r}$ conditions. The interpillow material at Palovaara is mainly composed of amphibole or amphibole \pm pidote. The amphibole is clearly metamorphic after chlorite, which was the original hydrothermal mineral. These assemblages correspond to $\mathrm{w} / \mathrm{r}$ ratios in excess of
30 and $30-12$, respectively, provided that the conditions are comparable with those in the experimental studies (Fig. 7). The dark fractures and schlieren elsewhere in intermediate and mafic rocks can also be interpreted as the combined products of hydrothermal alteration under high $\mathrm{w} / \mathrm{r}$ ratio conditions and later regional metamorphism.

The dominant mineral assemblage in both massive lavas and albite diabases is albite + amphibole + epidote + magnetite, corresponding to low w/r ratios (in Fig. 7 clearly less than 12, at which albite begins to form). If these rocks are altered in a w/r system, a diffusion of fluids through large masses of rocks is implied. Corresponding findings from Na-enriched Precambrian volcanics have been reported by Lagerblad and Gorbatschev (1985). The absence of chlorite from the massive rocks at Palovaara may be due either to metamorphism or to the fact that the very low $\mathrm{w} / \mathrm{r}$ did not allow chlorite to form in the massive lavas and albite diabases.

The chemical compositions in Table 1 show that in relation to corresponding unaltered compositions, the lavas are clearly more thoroughly altered than diabases. This suggests that the $\mathrm{w} / \mathrm{r}$ ratio in the diabases was lower than that in the lavas.

The total absence of epidote from one mafic massive flow indicates a high $\mathrm{w} / \mathrm{r}$ ratio. Yet the high $\mathrm{Na}$ and $\mathrm{Si}$ of this flow suggest the opposite. This contradiction can be resolved in one of two ways: either chemical and mineralogical balance between the hydrothermal fluids and the lavas was never achieved or the $\mathrm{CO}_{2}$ content of the hydrothermal fluids was high enough to prevent epidote from forming (Winkler 1979), even if the $\mathrm{w} / \mathrm{r}$ ratio had been high enough for epidote to form. The latter explanation seems the more plausible because the carbonate content of this flow is higher than in the other flows. The presence of rutile instead of sphene also supports this interpretation (Hunt and Kerrick 1977).

If the inter-pillow matrix and related secondary ultramafic assemblages are hydrothermal in ori- 


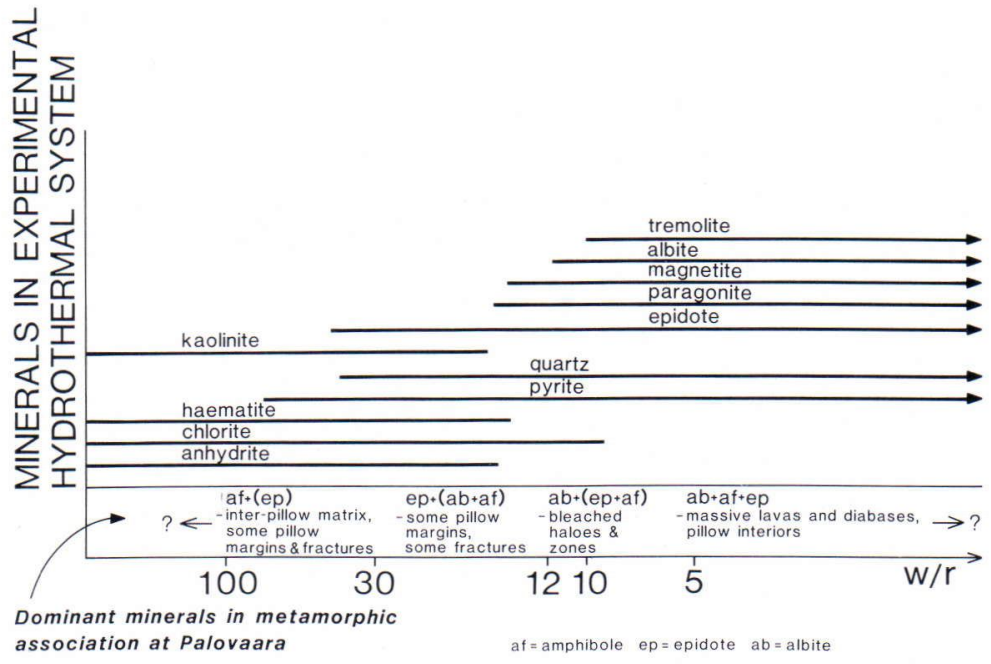

Fig. 7. Minerals formed in a reaction between basalt and sea water at varying water/rock (w/r) ratios under hydrothermal conditions $\left(\mathrm{T}=300^{\circ} \mathrm{C}\right.$ ) (modified from Mottl and Holland 1978; Reed 1983). The approximate positions of the metamorphic assemblages from mafic and intermediate igneous rocks at Palovaara are outlined in the lower part of the diagram.

gin, then it is reasonable to assume that the strongly albitized (bleached) haloes around them were generated by the same processes. This would indicate $\mathrm{w} / \mathrm{r}$ conditions intermediate between those in the ultramafic areas and those in massive rocks, i.e. a $\mathrm{w} / \mathrm{r}$ ratio of about or slightly less than 12. Similar conditions apparently prevailed in the albite-rich veins and bleached zones not connected with secondary ultramafic assemblages. This interpretation is also supported by the observations of Alt et al. (1986), who described albitized haloes around fractures in hydrothermally altered dykes of recent unmetamorphosed oceanic crust.

The texture and chemical compositions of the tuffs and tuffites, though somewhat modified by chemical and epiclastic deposition, clearly indicate that they, too, were altered by $\mathrm{w} / \mathrm{r}$ reactions. The permeability of these rocks and the temperature of the metasomatizing fluids may have differed from those in magmatic rock types; the absolute $\mathrm{w} / \mathrm{r}$ ratios may also have been quite different. We can conclude that the bleached fractures in these rocks are due to $\mathrm{a} w / \mathrm{r}$ ratio that was higher than that in the homogeneous host rocks.

Finally, the increase in $\mathrm{K}$ seen in some samples was shown to postdate the albitization, i.e. the Na-metasomatism of the volcanic pile at Palovaara. The cause of the K-metasomatism is not known but it may well be a part of the same hydrothermal system that gave rise to the Nametasomatism. This would imply a decrease in temperature and/or $\mathrm{pH}$ of the metasomatizing hydrothermal fluids, as demonstrated by Munha et al. (1980), Hajash and Chandler (1981) and Urabe and Scott (1983).

\section{Conclusion}

The lower part of the early Proterozoic greenstone complex at Palovaara in Enontekiö, northwestern Finland, comprises a quartzite formation overlain by felsic and intermediate tuffs and tuffites with some predominantly intermediate lava flows. The pile is intruded by numerous sills 
of albite diabase and finally by some minor keratophyric dykes.

The lithology and geochemistry of the rocks are similar to those of the spilite-keratophyre association and provide evidence that the rocks were thoroughly altered by postcrystallization processes.

Geochemically, all the rock types, including the extrusive and subvolcanic varieties, are greatly enriched in $\mathrm{Na}$ and depleted in $\mathrm{K}$ and $\mathrm{Mn}$. The alteration resembles that observed in recent submarine volcanics, whose mineralogy is largely governed by the water/rock ratio during alteration. Subsequent regional metamorphism had only a minor, if any, effect on the geochemistry of the rocks but adjusted the mineralogy to the conditions of epidote-amphibolite facies.

\section{References}

Alt, J.C. \& Honnorez, J., 1984. Alteration of the upper oceanic crust, DSDP site 417: mineralogy and chemistry. Contrib. Mineral. Petrol. 87, 149-169.

-, Honnorez, J.; Laverne, C. \& Emmerman, R., 1986. Hydrothermal alteration of a $1 \mathrm{~km}$ section through the upper oceanic crust, Deep Sea Drilling Project hole 504B: mineralogy, chemistry, and evolution of seawaterbasalt interactions. J. Geophys. Res. 91, 10 309-10 335.

Ambros, M., 1980. Beskrivning till berggrundskartorna Lannavaara NV, NO, SV, SO och Karesuando SV, SO. Sver. Geol. Unders. Ser. Af Nr. 25-30.

Edmond, J.M.; Measures, C.; McDuff, R.E.; Chan, L.H.; Collier, R.; Grant, B.; Gordon, J. \& Corliss, J.B., 1979. Ridge crest hydrothermal activity and the balances of the major and minor elements in the ocean: the Galapagos data. Earth Planet. Sci. Lett. 46, 1-18.

Eskola, P., 1925. On the petrology of eastern Fennoscandia I. The mineral development of basic rocks in the Karelian formation. Fennia 45, 19, 1-93.

Fiala, F., 1974. Some notes on the problem of spilites. in Amstutz, G.C. (ed.) Spilites and spilitic rocks. IUGS, Ser. A, No. 4, SpringerVerlag, Berlin. pp. 9-22.

Floyd, P.A. \& Winchester, J.A., 1978. Identification and discrimination of altered and metamorphosed volcanic rocks using immobile elements. Chem. Geol. 21, 291-306.

Geological Map of Northern Fennoscandia $1: 1$ mill. Geological Surveys of Finland, Norway and Sweden, Helsinki 1987, ISBN 91-7 158-370-x.
The impact of alteration was strongest in the channels of the metasomatizing fluids, such as pillow lavas, fractures and brecciated zones. The mineral assemblages and geochemistry of massive lavas and diabases indicate much lower $\mathrm{w} / \mathrm{r}$ ratios. A K-metasomatic event caused local biotitization and raised the $\mathrm{K}$-content in some places. The K-metasomatism may have been the latest phase in the hydrothermal system that originally caused the Nametasomatism and leaching of $\mathrm{K}$ and $\mathrm{Mn}$.

Acknowledgements. We thank Prof. Heikki Papunen, Prof. Atso Vorma and Mr. Eero Hanski for their constructive comments on the manuscript; Mr. Väinö Hoffren for making four silicate analyses; Mrs. Ritva Forsman and Miss Liisa Sirén for drawing and Mrs. Gillian Häkli for correcting the English.

Hajash, A. \& Chandler, G.W., 1981. An experimental investigation between seawater and rhyolite, andesite, basalt and peridotite. Contr. Mineral. Petrol. 78, 240-254.

Hanski, E., 1984. Geology of the gabbro-wehrlite associationoin the eastern part of the Baltic Shield. Arkeeisten alueiden malmiporojekti, raportti no. 20, Oulun yliopisto, $78 \mathrm{p}$,

-, 1986. The Gabbro-wehrlite Association in the Eastern Part of the Baltic Shield. in Friedrich, G.H. et al. (eds.) Geology and Metallogeny of Copper Deposits, SpringerVerlag Berlin Heidelberg, pp. 151-170.

-, 1987. Differentioituneet albiittidiabaasit- gabbrowehrliittiassosiaatio. in Aro, K. \& Laitakari, I. (eds.) Suomen diabaasit ja muut mafiset juonikivilajit (Diabases and other mafic dyke rocks in Finland), in Finnish with English summary. Geological Survey of Finland, Report of Investigation No. 76, pp. 35-44.

Hughes, C.J., 1973. Spilites, keratophyres and the igneous spectrum. Geol. Mag. 109, 513-527.

Hunt, J.A. \& Kerrick, D.M., 1977. The stability of sphene: experimental redetermination and geologic implications. Geochim. Cosmochim. Acta 41, 279-288.

Idman, H. \& Eilu, P., 1988. Granitoidien muuttuminen varhaisproterozooisen vihreäkivikompleksin länsireunalla Enontekiöllä - esimerkki kemiallisesta rapautumisesta. (Alteration of granitoids at the western margin of an earlyProterozoic greenstone complex at Enontekiö - an example of chemical weathering) in Finnish. Annales universitatis Turkuensis, Ser. C. Tom. 67, 39-52.

Ito, E. \& Andersson, A.T., 1983. Submarine metamorphism 
of gabbros from the Mid-Cayman Rise: petrographic and mineralogical constraints on hydrothermal processes at slow-spreading ridges. Contr. Mineral. Petrol. 82, $371-388$.

Janecky, D.R. \& Seyfrid, W.E. (1983) The solubility of magnesiumhydroxide-sulfate-hydrate in seawater at elevated temperatures and pressures. Am. J. Sci. 283, 831-860.

Kähkönen, Y., 1981. Oriveden ja Ylöjärven Proterozooiset vulkaaniset vyöhykkeet; erityisesti niiden geokemia. (The Proterozoic volcanic belts of the Orivesi and Ylöjärvi areas; especially their geochemistry), in Finnish. Unpubl. licenciate thesis, Dept. geol., Univ. Helsinki, 210 pages.

Lagerblad, B. \& Gorbatschev, R., 1985. Hydrothermal alteration as a control of regional geochemistry and ore formation inothe central Baltic Shield. Geologische Rundschau $74 / 1,33-49$.

Large, R.R., 1977. Chemical evolution and zonation of sulphide deposits in volcanic terrains. Econ. Geol. 77, 549-572.

MacKenzie, W.S.; Donaldson, C. \& Guilford, C., 1982. Atlas of igneous rocks and their textures. Longman, London. 148 p.

Le Maitre, R.W., 1976. The chemical variability of some common igneous rocks. J. Petrol. 17, 589-637.

Meriläinen, K., 1961. Albite diabases and albitites in Enontekiö and Kittilä, Finland. Bull. Comm. Geol. Finlande 195.

Mottl, M.J. \& Holland, H.D., 1978. Chemical exchange during hydrothermal alteration of basalt by seawater. Geochim. Cosmochim. Acta 42, 1 103-1 115.

Munhá, J. \& Kerrich, R., 1980. Sea water basalt interaction in spilites from the Iberian Pyrite Belt. Contr. Mineral. Petrol. 73, 191-200.

-, Fyfe, W. S. \& Kerrich, R., 1980. Adularia, the characteristic mineral of felsic spilites. Contr. Mineral. Petrol. $75,15-19$.

Paakkola, J., 1971. The volcanic complex and associated manganiferous iron formation of the Porkonen-Pahtavaara area in Finnish Lappland. Bull. Com. Geol. Finl. 247.
Piirainen, T.\& Rouhunkoski, P., 1974. General features of the spilitic rocks in Finland. In Amstutz, G.C. (ed.) Spilites and spilitic rocks. IUGS, Ser. A, No. 4. SpringerVerlag, Berlin, pp. 191-205.

Reed, M.H., 1983. Seawater-basalt reaction and the origin of greenstones and related ore deposits. Econ. Geol. 78, 466-485.

Roche, de la, H.; Rocci, G. \& Juteau, Th., 1974. Essai de characterisation chimique des associations spilitiques. In Amstutz, G.C. (ed.) Spilites and spilitic rocks, IUGS, Ser. A, No.4, Springer-Verlag, Berlin. pp. 59-68.

Schermerhorn, L.J.G., 1973. What is keratophyre? Lithos $6,111$.

Seyfried, W. \& Bischoff, J.L., 1977. Hydrothermal transport of heavy metals by seawater: the role of seawater/basalt ratio. Earth Planet. Sci. Lett. 34, 71-77.

Sivell, W.J. \& Waterhouse, J.B., 1984. Ocean ridge meta morphism of the Patuki Volcanics, D'urville Island, New Zealand. Lithos, 17, 19-36.

Skiöld, T., 1986. On the age of the Kiruna greenstones, northern Sweden. Precambrian. Res. 32, 35-44.

Spooner, E.T.C.; Chapman, H.J. \& Smewing, J.C., 1977. Strontium isotopic contamination and oxidation during ocean floor hydrothermal metamorphism of the ophiolitic rocks of the Troodos Massif, Cyprus. Geochim. Cosmochim. Acta 41, 873-890.

Staudigel, H.; Hart, S.R. \& Richardson, S.H., 1981. Alteration of the oceanic crust: processes and timing. Earth Planet. Sci. Lett. 52, 311-327.

Urabe, T. \& Scott, S.D., 1983. Geology and the footwall alteration of the South Bay massive sulphide deposit, northwestern Ontario, Canada. Can. J. Earth Sci. 20, 1826-1879.

Winkler, H. G., 1979. Petrogenesis of metamorphic rocks. Spinger-Verlag, New York. 348 p.

Witschard, F., 1984. The geological and tectonic evolution of the Precambrian of the northern Sweden - a case for basement reactivation? Precambrian Res. 23, 273-315.

Received August 15, 1988

Revised and accepted November 24, 1988 